the spread of the germs of diseases from one country to another by the intervention of winds, it had been perhaps universally assumed that it is only the winds blowing over or near the surface of the earth which were concerned in the dissemination of these germs. Generally it has been concluded that, if the surface winds do not account for the successive appearances of the epidemic at different points, the germs have not been transported by the winds. This, however, is only a mode of looking at the" subject which ignores the recent developments of meteorology and its teachings regarding atmospheric circulation through cyclones and anticyclones. As is now virtually proved, the winds in a cyclone are drawn inwards towards its centre, and thence ascend in a vast aërial column to the upper regions of the atmosphere, whence again they flow as an upper current towards any anticyclone or anticyclones that may be in the surrounding region. Thereafter they slowly descend down the centre of the anticyclone to the earth's surface, over which they are carried in every direction. Thus, for example, from a cyclone in Russia, a vast column of air rises from the surface, carrying with it particles of dust, germs, and other light impurities. These are then conveyed by the upper current to the anticyclone that may at the time overspread Western Europe, and thereafter descend to the surface, and are then distributed over Western and Central Europe by winds from all points of the compass. Owing to the rapidity of these aërial movements, two or at most three days are amply sufficient for this distribution.

\section{MATHEMATICAL TEACHING AT THE SORBONNE, I809-1889.}

THE following brief sketch of the illustrious Professors who have during the last eighty years occupied the mathematical chairs at the Sorbonne is founded upon an interesting address by the veteran mathematician, M. Ch. Hermite.

The occupants, in 1809, of the respective chairs, were Lacroix (Differential and Integral Calculus), Poisson (Mechartics), Biot (Astronomy), Francoeur (the Higher Algebra), and Hachette (Descriptive Geometry). Each, in his respective department, has left traces of his power which are still in evidence. "Nous évoquons le souvenir de ces hommes éminents qui ont honore la Faculté des Sciences à son origine; nous voulons rendre l'hommage qui est dû̀ leur mémoire, et dans cette circonstance rappeler leurs titres à la reconnaissance du pays." M. Hermite then proceeds to analyze in turn the work of the above Professors.

(I) Of Lacroix, he says: "La constante préoccupation de l'auteur a été d'établir entre tant de théories qu'il expose, sur des matières si diverses, une succession naturelle, un enchaînement qui en facilite l'étude et contribue à l'intelligence générale de l'analyse." He was well followed by Lefébure de Fourcy.

(2) Francœur occupied his chair down to 1847 ; he was the author of a long list of works. " "La concision que s'est imposée l'auteur pour réunir tant de matières dans un court espace ne porte jamais atteinte à la clarté." A sketch of the "Uranographie " is furnished by M. Tisserand.

(3) Biot was also a long occupant of his chair, "dont il est resté titulaire jusqu'en 1 846 ." $M$. Wolf furnishes a note (pp. 36-40) which gives a full account of the "Traité Elémentaire d'Astronomie physique." " Biot était un érudit et un écrivain," in M. Hermite's judgment.

(4) Poisson is a Colossus :- "Il figure parmi eux à côté de Laplace, de Lagrange, et de Fourier. C'est surtout de l'auteur de la 'Mécanique Céleste' qu'il se rapproche par la nature de ses travaux, son génie analytique, sa puissance pour mettre en cuvre toutes les ressources du calcul. Lagrange, à qui l'on doit la 'Mécanique Analytique,' et de grandes découvertes dans la théorie du son et la mécanique céleste, avait consacré une part importante de ses efforts aux mathématiques abstraites; après avoir fondé le calcul des variations, il a laissé la trace de son génie dans l'algèbre et la théorie des nombres. Pour Laplace et Poisson, l'analyse pure n'est point le but, mais l'instrument; les applications aux phénomènes physiques sont leur objet essentiel, et Fourier, en annonçant à l'Académie des Sciences les travaux de Jacobi, a exprimé le sentiment qui dominait à son époque, dans ces termes que nous reproduisons: 'Les questions de la

x “Discours prononcé devant le Président de la République, le 5 Aô̂t, l'inaugriration de la nouvelle Sorbonne, par M. Ch. Hermite, Professeur la Faculté des Sciences, Membre de l'Institut," Bulletin des Sciences Mathématiques, January 1890 (pp. $6-36)$. (Paris: Gauthier-Villars.) philosophie naturelle qui ont pour but l'étude mathématique de tous les grands phénomènes sont aussi un digne et principal objet des méditations des géomètres. On doit désirer que les personnes les plus propres à perfectionner la science du calcul dirigent leur travaux vers ces bautes applications, si nécessaires aux progrès de l'intelligence humaine.' Mais, en ayant un autre but, Poisson et Fourier contribuent au développement de l'analyse, qu'ils enrichissent de méthodes, de résultats nouveaux, de notions fondamentelles. Nous allons essayer de montrer l'importance des découvertes de Poisson dans la domaine de la physique mathématique, en jétant un coup d'œil rapide sur quelques-uns de ses mémoires."

(5) Poisson was succeeded by Sturm, whose reputation is founded upon his well-known theorem in the theory of equations. M. Hermite alludes to Prof. Sylvester's discovery in this branch.

(6) In 1838 , a Chair of Mécanique Physique et Expérimentale was founded, of which the first occupant was the illustrious Poncelet. Commencing with an account of the "Traite des Propriétés Projectives des Figures," the writer goes on to describe the other contributions of this eminent mathematician, who was succeeded (7) in $\mathbf{1} 85 \mathbf{I}$ by Delaunay. Here, again, M. Tisserand comes to the help of his colleague with an account of Delaunay's astronomical work.

(8) A short and highly appreciative account follows of Le Verrier. " "Il a été donné à l'illustre auteur de ne point laisser son œuvre inachevée; Le Verrier a corrigé sur son lit de mort les dernières feuilles de la théorie de Neptune, léguant à l'astronomie un monument impérissable qui sera l'honneur de son nom et de la science de notre pays."

(9) The various works of Lamé come next under review. "Lamé est un des plus beaux génies mathématiques de notre temps. Des découvertes capitales qui ont ouvert de nouvelles voies dans la théorie de la chaleur, la théorie de l'élasticité, l'analyse générale, le placent au nombre des grands géomètre dont la trace reste à jamais dans la science."

(Io) Liouville; (II) Serret; and (12) Duhamel are rapidly examined, the notice of this last being contributed by M. Bertrand.

(13) "Chasles est l'une des plus grandes illustrations de la Faculté; ses découvertes en géométrie, les ouvrages qu'il a publiés sur cette science l'ont placé au premier rang parmi les savants de l'Europe, et rendu son nom à jamais cèlèbre. De grandes et belles découvertes en mécanique se sont ajoutées à son œuvre principale, ainsi que des recherches d'érudition sur les mathématiques et l'astronomie des Indiens et des Arabes; nous indiquerons succinctement ces travaux qui ont jeté tant d'éclat, et sont présents à toutes les mémoires." The notice closes with the following touching sentence: "il nous reste à dire que ses amis et tous ceux qui ont connu notre cher et vénéré collègue gardent l'inaltérable souvenir de la bonté qui, chez le grand géomètre, était la compagne du génie."

(14) Cauchy is also treated at some length. "La vie du grand géomètre, remplie par des découvertes immortelles qui sont l'honneur de la science française, l'a été aussi par les ceuvres de la charité chrétienne et une inépuisable bienfaisance."

(15), (I6), and (17). In a few words are summed up the principal results obtained by other colleagues: "Nos collegues Puiseux, Briot, et Bouquet, morts il y a peu d'années, et dont nous gardons si affectueusement le souvenir, se sont inspirés de son génie, et ont consacré des travaux de premier ordre à poursuivre dans le domaine de l'analyse les conséquences de ses découvertes."

The speaker had a grand theme, and perhaps does not exalt too highly the very distinguished mathematicians who have preceded, or been associated with, him in his labours at the Sorbonne. One can pardon an occasional high-flown expression of his admiration for them and for their achievements : to ourselves the perusal of his discourse has furnished much pleasure, and we trust there will be as distinguished a roll of Professors to be celebrated when the work of the new Sorbonne has to be narrated by $M$. Hermite's successor. We conclude with the closing words of the address :-

"Nous venons d'évoquer le souvenir de nos prédécesseurs, nous avons voulu rendre hommage à leur mémoire, rappeler leurs travaux, leurs découvertes, les grands exemples qu'ils nous ont laissés. Notre mission est de continuer leur œuvre, et d'ajouter à leur glorieux héritage ; ce devoir nous est rendu plus sacré par le don magnifique que nous tenons du pays, par sa généreuse assistance pour notre enseignement et nos travaux. Tous, maîtres 
de conférences et professeurs, nous y consacrerons notre dévouement, nos efforts : nous avons la confiance que, pour l'honneur de la Science et de la France, nous saurons fidèlement le remplir."

\section{SCIENTIFIC SERIALS.}

The American Journal of Science, April 189o.-On the æolian sandstones of Fernando de Noronha, by John C. Branner. These sandstones lie upon the eastern or south-eastern sides of the island, at an elevation of 70 feet on Ilha do Meio, 90 feet on São José, and about Ioo feet on the Ilha Rapta, and at the base of Atalaia Grande. The author has closely investigated the formation, and finds that the material was originally deposited in the form of sand-dunes blown up by winds from the south or south-east. Analyses of several specimens of the rock are given.-A mountain study of the spectrum of aqueous vapour, by Charles $S$. Cook. The author has devised a means of producing an artificial line whose intensity can be varied at will alongside the line whose intensity is required. The variations in the blackness of the artificial line are effected by the use of a micrometer screw, the readings of which constitute an arbitrary value of intensities. It is found, (I) that the spectroscope studies vapour height primarily, and humidity only secondarily; (2) during stormy weather vapour ascends to altitudes greater than is usually supposed; (3) the great absorption of storm clouds is due to their great thickness, or to extensive strata of damp air associated with them, more than to any peculiar behaviour as clouds.-On the occurrence of basalt dykes in the Upper Palæozoic series in Central A ppalachian Virginia, by Nelson $H$. Darton; with notes on the petrography, by $J$. S. Diller.-Additional notes on the tryolite from Utah, by $\mathrm{W}$. F. Hillebrand and E. S. Dana. The composition and crystalline form of this mineral are considered. -W. S. Bayley, on the origin of the soda-granite and quartz-keratophyre of Pigeon Point, Minnesota. These rocks have been previously described by the author (Amer. Fourn., January I889). In the present note the reasons are pointed out which lead to the conclusion that the red rock is of contact origin, and produced by the action of the gabbro upon the slate and quartzites.-Frank. Waldo, in recent contributions to dynamical meteorology, gives a general idea of the nature of each of fourteen papers on meteorology most of the papers being by German physicists. The attitude of the writers towards meteorology is also indicated by reference to other work done in the same direction.-Two methods for the direct determination of chlorine in mixtures of alkaline chlorides and iodides, by F. A. Gooch and F. W. Mar.-On the occurrence of polycrase, or of an allied species, in both North and South Carolina, by W. E. Hidden and J. R. Mackintosh. The analyses, so far as they go, show that a mineral previously noticed (Amer. Fourn, November 1888) is very closely allied to, if not identical with, the polycrase from Hitteroe, Norway, analyzed by Rammelsberg. - Origin of some topographic features of Central Texas, by Ralph S. Tarr.--On the formation of silver silicate, by J. Dawson Hawkins. A simple method for the preparation of this compound is described. The reaction made use of is $\mathrm{Na}_{2} \mathrm{SiO}_{3}+2 \mathrm{AgNO}_{3}=\mathrm{Ag}_{2} \mathrm{SiO}_{3}+2 \mathrm{NaNO}_{3}$.

\section{SOCIETIES AND ACADEMIES}

\section{LONDON.}

Royal Society, April 17.- "Preliminary Note on Supplementary Magnetic Surveys of Special Districts in the British Isles." By A. W. Riicker, M. A., F.R.S., and T. E. Thorpe, Ph.D., B.Sc. (Vict.), F.R.S.

During the summer of 1889 we carried out additional magnetic surveys of the Western Isles and the West Coast of Scotland, and of a tract of country in Yorkshire and Lincolnshire.

Both districts were selected with special objects in view. We had found that powerful horizontal disturbing forces acted west. wards from the Sound of Islay, from Iona, and from Tiree, and we had deduced a similar direction for the disturbing force at Glenmorven from Mr. Welsh's survey of Scotland in I857-58. The whole district presents peculiar difficulties, partly from the fact that local disturbance is likely to mask the effects of the regional forces, partly because the normal values of the elements must be especially uncertain at stations on the edge of the area of our survey.

If, then, the general westward tendency of the horizontal disturbing forces was due to some source of error, stations in the extreme south of the Hebrides would in all probability be similarly affected. If the directions of the forces were due to a physical cause, such as a centre of attraction out at sea to the west of Tiree, then the disturbing forces in the Southern Hebrides would almost certainly be directed southwards towards it.

The observations made last summer prove (I) that the direction of the disturbing horizontal force at Bernera, which is the southernmost island of the Hebridean group, is due south; and (2) that, as this point is approached from the north, the down ward vertical disturbing attraction on the north pole of the needle regularly increases, which exactly agrees with the sup. position that a centre of attraction is being approached.

There is, therefore, now no doubt that there is a centre of attraction on the north pole of the needle to the south of the Hebrides and to the west of Tiree.

(2) In one of the maps communicated to the Society last year we drew two lines, bounding a district about 150 miles long and 40 miles broad, in Yorkshire and Lincolnshire, and gave reasons for the belief that a ridge line or locus of attraction lay between them.

This conclusion has now been tested by means of thirty-five additional stations, with the following results :-

(I) At all stations (with one exception) on or near the two lines, the horizontal disturbing forces tend towards the centre of the district they bound.

(2) The downward vertical disturbing forces are greater in the centre of the district than at its boundaries. In particular, there are two well-marked regions of very high vertical force.

(3) The greatest vertical force disturbances occur at Market Weighton, where the older sedimentary rocks are known to approach the surface, and at Harrogate, which is on the apex of an anticlinal.

(4) The central ridge line runs from the Wash parallel to the line of the Wolds to Brigg. Thence it appears to turn west, and reaches Market Weighton viâ Butterwick and Howden. One or two additional stations are, however, required to determine whether this bend is real, or whether the line runs direct from Brigg to Market Weighton. From the latter town it passes to the limestone district of Yorkshire and traverses its centre. It has not yet been traced west of the line of the Midland Railway between Settle and Hawes, but there is ground for believing that it continues to the Lake District.

Although, therefore, one or two points of detail remain for further investigation, the existence of a line of attraction 150 miles long is proved beyond the possibility of doubt, and for about 90 miles its position is known to within 5 miles.

There are, then, even in those parts of England where the superficial strata are not magnetic, regions of high vertical force comparable in size with small counties, and ridge lines or loci of attraction as long and almost as clearly defined as the rivers. Their course is closely connected with the geology of the districts through which they run.

Royal Meterological Society, April I6.-Mr. Baldwin Latham, President, in the chair.-The following papers were read :-The cold period at the beginning of March 1890 , by Mr. C. Harding. At the commencement of the month a rather heavy fall of snow was experienced in many parts of England, and very cold weather set in over the midland, eastern, and southern districts, the temperature on the 3 rd and 4th falling to a lower point than at any time in the previous winter. The lowest authentic thermometer readings, in approved screens, were $5^{\circ}$ at Beddington, $6^{\circ}$ at Kenley in Surrey and Hillington in Norfolk, $7^{\circ}$ at Chelmsford and Beckenham, $8^{\circ}$ at Addiscombe, $9^{\circ}$ at Reigate and Brockham, and $10^{\circ}$ in many parts of Kent and Surrey. At Greenwich Observatory the thermometer registered $13^{\circ}$, which has only once been equalled in March during the last IOO years, the same reading having occurred on March I4, I 845 . During the last half-century the temperature in March has only previously fallen below $20^{\circ}$ in three years, whilst during the whole winter so low a temperature has only occurred in eight years. - Note on the whirlwind which occurred at Fulford, near York, March 8, 1890, by Mr. J. E. Clark. A sharp and heavy thunderstorm occurred at York about 2.30 p.m. At the same time, or shortly afterwards, a whirlwind passed a little to the south of the city, from Bishopthorpe to Heslington, a distance of about 